\title{
Focusing the kaleidoscope: exploring distributed leadership in an English university
}

Article

Accepted Version

Floyd, A. and Fung, D. (2015) Focusing the kaleidoscope: exploring distributed leadership in an English university. Studies in Higher Education, 2015. ISSN 0307-5079 doi: https://doi.org/10.1080/03075079.2015.1110692 Available at https://centaur.reading.ac.uk/69430/

It is advisable to refer to the publisher's version if you intend to cite from the work. See Guidance on citing.

To link to this article DOI: http://dx.doi.org/10.1080/03075079.2015.1110692

Publisher: Taylor \& Francis

All outputs in CentAUR are protected by Intellectual Property Rights law, including copyright law. Copyright and IPR is retained by the creators or other copyright holders. Terms and conditions for use of this material are defined in the End User Agreement.

www.reading.ac.uk/centaur

\section{CentAUR}


Central Archive at the University of Reading

Reading's research outputs online 


\title{
RESEARCH ARTICLE
}

\section{Focusing the kaleidoscope: Exploring distributed leadership in an}

\section{English university}

\author{
Alan Floyd* (a) and Dilly Fung (b) \\ (a) Faculty of Education and Language Studies, The Open University \\ (b) Centre for the Advancement of Learning and Teaching, University College London \\ * denotes corresponding author \\ Faculty of Education and Language Studies \\ The Open University \\ Walton Hall \\ Milton Keynes MK7 6AA \\ Email: alan.floyd@open.ac.uk
}




\title{
Focusing the kaleidoscope: Exploring distributed leadership in an English university
}

\author{
In the UK and elsewhere, the idea of 'distributing leadership' in universities is \\ becoming more popular. Yet, there is surprisingly little research on this topic. \\ This paper reports on a funded study which explored how one institution had \\ implemented a newly conceived 'distributed' leadership model, specifically to \\ investigate the impact of the model on the academics who had taken on the new \\ leadership positions within the university. The study adopted an exploratory, \\ sequential mixed methods design with in-depth interviews $(n=30)$ being \\ undertaken first, followed by an online survey $(n=177)$. The findings suggest that \\ the challenge of 'distributed leadership' in universities is complex on a number of \\ levels: the plurality of the institutional mission; the diversity of possible \\ leadership/management roles; the challenge of effective communication; and the \\ effects of traditional academic values and identities, which may support but may \\ also be antithetical to the strategic direction of the institution.
}

Keywords: identity; university purpose; values; communication.

\section{Introduction}

Now, more than ever, higher education institutions in the UK and elsewhere are reflecting on the need for effective leadership models which enable individual members of staff, their departments and the institution as a whole to adapt to a quickly changing academic environment (Flumerfelt and Banachowski 2011, Osseo-Asare, Longbottom, and Chourides 2007, Randall and Coakley 2007, Holt et al. 2014). The characteristics of 'effective' leadership are open to question, however, particularly in a higher education sector in which rapid shifts in policy and funding are contributing to a kaleidoscopic ‘supercomplexity' (Barnett 2000) of challenges, structures, processes and value frameworks. In the UK, with the publication of the Browne Report (2010), the subsequent increase in student fees in 2012/2013, and the influential National Student 
Survey with its impact on higher education league tables, there is pressure on researchintensive institutions to focus on improving teaching quality. At the same time, such institutions are under increasing pressure to perform well in the UK Research Excellence Framework, respond to the incipient 'avalanche' (Barber, Donnelly, and Rizvi 2013) of rapid developments in technology and the rise of the Massive Open Online Course (MOOC), and deal with turbulence in the international market and political landscape. Even more fundamentally, institutions are being challenged to consider their own nature and purpose in the modern era (Bolden, Gosling, and O'Brien 2013): what might being an 'authentic university' (Barnett 2011) mean at a time when institutions are both businesses with an international market, and organisations with a global mission to extend knowledge through both research and teaching? And, with such multi-layered organisational purposes, how are structures and roles developing in response to these multiple institutional identities and possibilities?

The purpose of this paper is to examine these issues through the prism of the findings of a study funded by the Leadership Foundation for Higher Education which explored how one institution had responded to the ever changing higher education climate by implementing a newly conceived 'distributed' leadership model. The model involved appointing 130 academics to the position of Academic Lead (AL) throughout the university, a role which was to provide leadership and support to a small group of individual academic colleagues in their discipline or subject grouping. The model will be outlined in more detail in the context section. The main aims of the research project were to explore how the model had been implemented and look at the impact of the model on both those who were leaders and those being led.

While the notion of distributed leadership has been explored widely in school 
leadership research (Mayrowetz 2008, Spillane, Halverson, and Diamond 2007, Woods et al. 2004), it has been less widely applied to research exploring the higher education sector (Bryman 2009). Thus, in addressing this apparent knowledge gap, this article investigates the impact of the model on the academics who have taken on new leadership positions within the institution, and examines the ways in which their personal perspectives shed light upon the complex leadership challenges currently facing research-intensive universities in the UK. Specifically, it aims to address the following research questions (RQs):

- How do Academic Leads describe and understand their experiences of being in the role?

- What is the subsequent impact of taking on these new roles on their academic identities and core value systems?

Following this introduction, we outline the paper's theoretical framework. Next, we provide some context to the newly implemented 'distributed leadership' model. We then discuss the methodological choices taken and present our findings and analysis. Finally, we discuss these findings and highlight some of the implications for practice.

\section{Theoretical Framework}

\section{Distributed leadership}

As mentioned above, the notion of distributed leadership has been explored widely in school leadership research (see Gronn 2008 for an excellent discussion of this topic), but has been less well used in higher education research. Underpinning the concept is a recent paradigm shift in viewing leadership practice in organisations as being shared across an institution or group rather than being undertaken or 'owned' by one person. 
This shift reflects current thinking in leadership theory which has evolved from:

... its original sole focus on the traits, skills and behaviours of individual leaders...to acknowledge the importance of context, situation, environment and contingency...(Jones et al. 2014, 604)

Bolden et al. $(2008,258)$ explain the concept in relation to higher education, while highlighting some of the knowledge gaps in this area:

...the HE sector in the UK is increasingly espousing the practice of 'distributed leadership'...whereby leadership is conceived of as a process dispersed across the organization (within systems, activities, practices and relationships) rather than residing within the traits, actions and/or capabilities of 'leaders' in formal positions. Despite having embraced this concept, however, it is still not clear what is actually distributed (in terms of power or accountability), the processes by which it is distributed, or whether the concept itself offers substantial benefits for either practice, analysis or policy-making.

While research into this area appears relatively sparse, recent research in Australia seems to suggest that adopting distributed leadership models in higher education can be successful (Harkin and Healy 2013) with the approach proving especially useful in relation to leading the quality management of on-line learning environments (Holt et al. 2013, Holt et al. 2014) and in building leadership capacity in learning and teaching (Jones et al. 2014, Jones et al. 2012). What is less clear, however, is how useful adopting a distributed leadership model is in relation to supporting academic staff in a research-led environment, which is something this paper hopes to address.

Arguably, 'distributing' leadership is even more important in higher education institutions than in other organisations as academics are well educated, largely autonomous and trained to be highly critical and so are more likely to oppose and challenge more traditional leadership models and behaviours. Indeed, Bryman (2007) 
contends that academics, because of their education and professional status, may need a different or more subtle form of leadership than other occupational groups, and that any such leadership practice needs to take into account an academic's possible ability to neutralise the impact of leadership behaviour given their 'professional orientation and a need for independence' (706). In addition, there is evidence to suggest that so called 'grassroot leadership' in higher education - from academics who are not in formal leadership positions - can effect real change, even though such actions are often not endorsed by senior leaders (Kezar, Bertram Gallant, and Lester 2011). Thus, distributed leadership models in higher education need to be examined by exploring the interface between the perceived agency, identities and values systems of the leaders and the led, together with those of the organisational structures in which they are working; this analytical approach has been adopted in the study presented here and is developed in full in the next section.

\section{The nature and purpose of higher education}

Alongside the concept of distributed leadership, underpinning this study are philosophical questions about the nature of higher education, its purpose and institutional identity. Is a modern day research-intensive university a business, whose first priority is to maximise outputs, or should its organisational shape reflect first and foremost the characteristics and values of a research and learning community? Barnett (2011) argues that traditionally the 'idea' of the university stood for the 'highest realisation of human being', but that there has been a 'recent lurch in the directions of the entrepreneurial university and the corporate university' (318). Yet, for all the political and economic imperatives and the subsequent requirements for an institution to succeed as a business, the university 'retains pools of autonomy' (273) and can make 
choices with respect to its direction of travel. He goes on to argue that universities should expand their thinking, energy and imagination, so that each institution is 'working out what its maximum possibilities are for advancing learning and inquiry against a horizon of universality' (Barnett 2011, 289). Within this context:

A task of university leadership, accordingly (and unlike university 'management'), is that of infusing a university with energy, with spirit. (Barnett 2011, 315-316)

Crucially, though, any re-framing of leadership within an institution conveys a set of values about what that institution's purpose is, and how its academic leaders - and 'followers' - are positioned within that organisation. Does a particular leadership approach 'infuse ... with energy', or does it aim to 'manage' academic work and productivity? Can it do both?

Within the context of these normative questions about what a university might be, and the possible roles and purposes of its leaders, we are also interested in how these institutional issues are experienced at the level of the individual academic: how does taking on a leadership role affect an academic's professional identity and underlying value system? Winter $(2009,121)$ suggests that academic managers share values 'congruent with managerial discourse' while managed academics share values that are 'incongruous with managerial discourse' and this consequently contributes to an 'identity schism' for academics because of irreconcilable value systems between the organisation and the individual; between the academic manager and the managed academic. However, this argument appears to have two flawed underlying assumptions: first, that all centrally held organisational values are somehow negative and viewed pejoratively by academics and, more importantly for this paper, that all academic managers share these values. What if an organisation's centrally espoused and enacted 
value system is not totally incongruous with an academic's? Or, conversely, what about academic leaders who continue to lead and manage adhering to their deeply held personal beliefs and value systems that they have developed by becoming and being an academic, deliberately pushing against organisational values and subsequent activities that they do not agree with and that they perceive as conflicting with their own? Thus, our framework aims to explore how academic leader identities and values interact with the identity and values of the institution - exploring the interaction between individual agency and organisational structure - in order to connect up the larger philosophical questions about the nature of/possibilities for a university and the nature of/possibilities for the academic leader in the current higher education climate.

\section{Context}

Sunnyside (name changed for ethical reasons) is a research-led University in the UK with approximately 18,500 students and 1,100 academic staff. In 2010, in attempting to respond to the external forces currently affecting HE institutions in the UK (as outlined earlier), Sunnyside went through a restructuring process moving from eight subjectbased Schools into four larger Colleges. As part of this process, a new Academic Lead (AL) role was introduced in an attempt to build leadership capacity in the newly formed Colleges. Figure 1 below shows the generic leadership and management structure that each College had in place.

[Figure 1 to be placed here]

It was envisaged that, at a discipline level, ALs would work closely with Directors of 
Education and Directors of Research to provide leadership, guidance, support and advice to a group of individual academic colleagues in their discipline or subject grouping (normally a group of about eight staff), as well as contributing to the decision making processes around resource allocation. ALs would also be members of the 'senior management group' of the College so that they were kept well informed about College priorities and strategies and able to engage with College wide decision-making. Alongside the introduction of the AL role, a new Performance and Development Review (PDR) system was launched to facilitate the translation of institutional strategies into individual objectives, while at the same time accommodating academics' personal goals and ambitions. One of the key ideas underpinning distributed leadership and the PDR process at Sunnyside was that ALs, Directors of Research and Directors of Education would co-ordinate their actions so that personal goals agreed through the PDR process were holistic and proportionate, and that individual academics were well supported; the model was supposedly underpinned by an intention to bring into harmony the needs and values of the institution and its individual staff. Between 2010 and 2013, more than 130 academic staff were appointed to the AL role.

An important point to make here is that at Sunnyside there are two different academic job 'families': Education and Research and Education and Scholarship, with each having their own contracts and slightly different focus within the Institution. Academics in the Education and Research group, who are actively researching in their field and required to meet targets in relationship to research income and academic publications, outnumber their more education-focused academic colleagues by approximately 4:1, although this proportion varies considerably in different parts of the institution. The Education and Scholarship academics are typically not (currently) actively researching in their field, but have a significant teaching load. They may take 
on Director of Education (DoE) roles as they progress in their career, although DoE roles are also taken up by the 'research active' academics. It is possible in principle at Sunnyside for all academics to gain promotion to full Professor, if they meet certain criteria in relation to research, success and impact in their field and/or the scholarship of teaching and learning in higher education.

\section{Methods}

To answer our research questions, we adopted a two staged, mixed methods approach (Bryman 2008). In doing so, we used an embedded mixed methods design (Cresswell 2014), where the whole study was framed within a humanistic philosophical framework (Newby 2010). Underpinning this framework is an understanding of the value of human experience as central to data collection and analysis, and that experiences are socially constructed and interpreted differently by individuals depending on a range of cultural, historical and situational factors.

Specifically, we used an exploratory, sequential mixed methods design (Cresswell 2014) where qualitative data are gathered and analysed first, before quantitative data are collected from a larger sample size. Thus, in stage one, we conducted qualitative research undertaking interviews with 15 Academic Leads (ALs) and 15 Assigned Academics (AAs) - that is, academics who had been assigned to Academic Leads - about their experiences and perceptions of the role (three from each College $)$. The sample contained male $(\mathrm{ALs}=9 ; \mathrm{AAs}=8)$ and female $(\mathrm{ALs}=6 ; \mathrm{AAs}=7)$ staff with a range of ages, levels of experience and discipline backgrounds. Table 1 shows the participants from each interview group (ALs and AAs), together with their age ranges and broad academic domain areas. To ensure anonymity for respondents, 
pseudonyms have been used throughout and all disciplines have been grouped into the umbrella terms of natural sciences, social sciences and humanities.

[Table 1 to be placed here]

Following ethical approval, participants were identified and invited to take part via email. Each participant was interviewed for approximately one hour and interviews were recorded and transcribed. The interview data were analysed using thematic analysis techniques outlined by Lichtman (2010). These data were supplemented with the analysis of key strategic documents linked to governance arrangements and working practices which helped in determining what management systems were in place to support the Academic Lead role and exploring how useful, or otherwise, they were. They were also used to determine the overall culture and working practices at Sunnyside, and the individual College cultures within which each participant worked. In order to examine whether the findings from stage one were indicative of staff perceptions and experiences across Sunnyside, in the second stage of the project we undertook a survey of all academic staff $(n=1034)$ using an online questionnaire (Bristol On-Line Surveys) which was based on themes and issues emanating from the first stage of the project and consisted of both closed and open ended questions. The questionnaire was developed and subject to an initial peer review, followed by a full piloting exercise. Subsequently, an invitation and link to the survey and was sent out via email to all staff with one reminder email sent two weeks later.

In total 177 people completed the survey giving a response rate of $17.1 \%$. The survey was completed by 42 academic leads (17 female and 25 male) which represents 
$32 \%$ of all ALs, and 135 assigned academics (69 female and 66 male) which represents just over $12 \%$ of academic staff at the University. The results of the survey were analysed and cross-tabulated to compare data from those who were academic leads with those who were assigned academics.

Figure 2 shows the survey breakdown by job title. The bar graph shows, not surprisingly, that the Academic Leads included a large percentage of senior staff with the vast majority (41 out of 42 respondents) being Professors, Associate Professors or Senior Lecturers.

[Figure 2 to be placed here]

The findings from both stages of the study have been combined and organised thematically. To maintain the focus of this article, the analysis that follows relates only to the data gathered from the Academic Leads and to their experiences and perspectives of being in the role.

\section{Findings}

\section{A role of contradictions}

From the data, it was evident that there was some variability in participants' understandings of the original purpose of the role, which fell broadly into two opposing groups. For the minority of interviewees, like Brandon, the purpose was clear from the start: it related to the need for a senior academic to take a holistic interest in the work and progress of the individual academics assigned to them: 
The theory, I think, is perfectly sensible... Who looks after a member of academic staff, whether they are teaching only or teaching and research, in the round? Who actually cares about the overall career development and performance of this individual in the round?

The participants who subscribed to this point of view saw the function of the new ALs as 'joining up' the messages from the other leaders with their diverse research and education portfolios:

I do think that instead of staff getting mixed messages about 'research is the most important thing in your life, forget everything else', or 'yes, go and develop that new degree programme and spend two years doing it', they're actually getting a single message.

However, clearly identifiable in almost all of the interviews, as well as in many of the comments made in response to the online survey, was a perceived conflict between the mentoring side of the new Academic Lead role and the line management function which appeared to sit alongside it. For example, Kendra described the role as:

...a slightly off mix of two things. The supportive, mentoring, coaching role, which is great - I understand that thoroughly - [but also] a more coercive management role.

The required balance between the two, she said, was unclear:

The mood music is all about mentoring, but there's also a very hard-nosed expectation.

And Evelyn said:

They want us to be poacher and gamekeeper at the same time.

Jack also recalled the early developmental session which focused on coaching and which was all related to: 
...how you have a nurturing role and act as a sort of confidante.

That, he said, was one of the problems:

There's this idea that everything that happens within that role is sort of almost like you're a priest or a doctor. You should be supportive and it shouldn't go any further. But that's actually problematic because you're actually the line manager... How can you be a neutral mentor?

This variability in understanding about the role was also found in the survey data, as shown in table 2. Although the majority of respondents appeared to be clear about the purpose of the role with 29 ALs (69\%) agreeing and only nine ALs (21\%) disagreeing with the statement, issues around role ambiguity can be seen more clearly when looking at the results in response to the statement The role boundaries are clearly defined. Here, 13 ALs (31\%) agreed with the statement while 18 ALs (43\%) disagreed.

One of the reasons that this variability exists could be down to the perceived communication issues felt by large numbers of Academic Leads. When asked whether they felt that information about the role had been communicated clearly to staff, 19 (45\%) ALs disagreed as opposed to only $11(26 \%)$ who agreed. In support of this view, Arthur felt that there were different conceptions and messages about the Academic Lead role operating at different levels of the organization:

We're told two very different things [about the role], depending on whether you ask the college or you ask the university. The university in all its communications and its training emphasized that this was a mentoring role purely. It's about trying to get the best out of your staff, and trying to help them fulfil their career goals and all that sort of stuff. The college sees it very differently, I think; the college sees it very much as a line management role... We are responsible for the performance of our team and for reporting on both the positives and negatives there in order that action can be taken. 
Communication issues will be discussed in more detail later in this section.

[Table 2 to be placed here]

\section{Mentor not manager}

There was a general agreement among the Academic Leads interviewed that the successful dimension of the AL role was characterised by mentoring rather than line management and this was confirmed through the survey data shown in table 2 which shows that the majority of ALs $(26 ; 62 \%)$ did not think that the role should focus on management functions.

Jack talked positively of how the AL should be there as an 'adviser', to 'help and encourage', and Martin appeared to speak for many ALs when he argued that:

You can't expect people to be completely candid about the mentoring side of stuff, if they know that this is being fed up to senior management in an environment that is at least perceived to be becoming increasingly top down. But ... I am very happy with the mentoring and supporting role.

Chris was one of a number who was happy with the AL label, but wanted to change it to a role which was wholly focused on supportive mentoring:

I might keep the name 'Academic Lead', but I'd change it to a mentoring role.

Reflecting on the ways in which they have made the role work in practice, the Academic Leads interviewed were able to give many examples of ways in which the role had made a positive impact. These positive dimensions extended beyond the oneto-one Academic Lead/assigned academic relationship to ways in which the Academic Leads as a group were able under certain circumstances to work constructively together. Diane, for example, described purposeful meetings: 
We have unit coordination group meetings, where the Director of Research, the Heads of Department and Director of Education meet with the academic leads and discuss issues that have come up [and] what the priorities are. And we talk about particular staff needs and interests, and I try and shape the division of teaching around what the staff needs and interests are. ... [We] really respect people's research needs as much as possible by having a dialogue [to discuss] what they really want to teach and what is best for their careers.

Oliver also found this dimension of the role particularly productive, talking of how it was good to have regular unit meetings to share issues openly:

It's a very informal meeting, so it's for all the academic leads and the heads of research to come together to discuss the way things are going.... They are really critical for people to keep in touch ...

In addition, many Academic Leads referred to the benefits of the mentoring side of the role. For Evelyn, mentoring was:

...the rewarding part of the job, because people appreciate it.

\section{Similarly for Chris:}

The positive aspect is the mentoring role... That's very valuable, I think; that could be developed.

And for Arthur:

It's all about the relationships you build up; I enjoy seeing people ... blossom, really develop.

The survey data (shown in table 2) also reflected the fact that the majority of staff were pleased with the mentoring aspect of the role with 30 ALs (71\%) agreeing with the statement I am happy with the mentoring aspect of the role and only $7(16 \%)$ disagreeing. In fact, the vast majority of ALs $(27 ; 64 \%)$ thought that the role should be 
mainly about mentoring staff, against only $5(12 \%)$ who disagreed.

In practice, the mentoring was characterized in terms of enabling assigned academics to progress in some substantive way. For example, Evelyn had worked with one academic assigned to her in order to help her to progress her career, which was struggling, by co-authoring a paper with her, to 'show her the ropes'. Similarly, Brandon talked of how:

...It's really great ... to be able to promote people's careers.

As a teaching-focused academic, he particularly appreciated being empowered to encourage other teaching-focused staff to apply successfully for grants relating to the scholarship of teaching and learning, and to free them up to take on some leadership responsibilities themselves in relation to curriculum or working with students so that they can become agents of change for the institution.

Other benefits for the Academic Leads themselves were alluded to in the interviews. For example, Jack, in seeing those he leads 'do very, very exciting things', felt 'more connected' to the academic community. And Evelyn talked about how even the administrative side of the Academic Lead role has 'legitimacy' in an academic setting. Through the administration, she said:

...you're actually contributing something to the university.

For the Academic Leads, there appeared to have been many examples of successful activity stimulated by the role. This point applies both to research-focused and to teaching-focused academics, and the interviews and survey data overall paint a picture of a range of very productive and meaningful activity arising from the relationships between Academic Leads and their assigned academics. 


\section{Crossed lines}

A number of difficulties and challenges, as conveyed by participants, stemmed from what were perceived as crossed lines of responsibility between the Academic Lead's role and that of other leaders: the Directors of Education, Directors of Research and (less commonly) Heads of Discipline (HoDs), who were sometimes referred to as Head of Department by the participants. Howard, for example, felt that the AL role:

...has interfered with [his] role as Director of Research', in that some of the discussions I used to have are now being done by somebody else.

He continued:

You either don't have certain discussions or you duplicate discussions with the Academic Leads, and then you run the risk of different messaging.

And Lisa observed that:

...the relationship between Head of Department and Academic Leads is not at all clear.

Oliver also commented:

I know they justify the Academic Lead as distributed leadership, however I think distributed leadership is one thing but distributed management is another. In the end ... you do need some management and boundaries, and by and large that tends to be done by someone who's head of the unit [HoD].

Diane spoke of a tension caused by lack of clarity about the ways in which those in Academic Lead roles should interact with other leadership roles:

[There are] not good communications within the university system about how Academic Leads work, how Directors of Education work, how Directors of 
Research work, and what is the role of the Heads of Department. I don't think anyone knows...

These frustrations were also evident from the survey data, although they did not reflect the majority view. In response to the statement I understand how the role fits into the management structure of the college 24 ALs (57\%) agreed, but 13 ALs (31\%) did not. Although a minority of the group as a whole, it is clear that a substantial number of people in Academic Lead positions did not seem to know how their role related to the overall college management structures.

\section{Responsibility without power}

Feeling powerless to change things was, for a number of ALs, also problematic. Arthur recalled that this tension was apparent from the time when the new role was introduced at an early developmental event:

I was trying to clarify just what the role meant and what the responsibilities were, and I think there was a great deal of nervousness amongst ALs that we could be made responsible for the people over whom we wielded no power. And I don't mean that in a sense of wanting to have that, but a worry that we're being put in an impossible position: we couldn't, other than through the good will of people we're leading, effect any change whatsoever and yet we might be responsible for their performance. ... And there's no budgetary control at all.

Similarly for Kendra, the difficult parts of the role were:

Helping colleagues who are particularly frustrated with aspects of their role, and dealing with things that ultimately we can't do anything about.

In relation to this problem, Martin identified that it was not possible, for example, to adjust the workload or the balance of responsibility between research and teaching in order to support his assigned academics or help them progress their careers: 
You don't, as an Academic Lead, have that kind of power; you don't have those decisions in your gift.

Chris illustrated the same point with a military analogy:

You're expected to be responsible and accountable, but you don't actually have the power to do anything. It's a bit like being a Lance Corporal, you've got the stripe and if anything goes wrong you get the blame, but actually everybody knows you're just a Lance Corporal so they're not really going to do very much of what you say, you have to go to the Sergeant Major to get any real bite.

\section{Communication}

As mentioned briefly earlier, communication was one of the most frequently evoked themes in this study. For those who had been moved from a smaller to a larger department, there has been a change in the culture of communication which had led to some discomfort. Martin had found it:

...difficult to adjust to a larger scale department ... where everyone has to be more routinized and so on.

He found the lack of opportunities for interpersonal, 'face to face' communication problematic. But for Diane, the issues were more systemic. Difficulties for Academic Leads arose, she said, from:

.... a big lack of communication, a massive lack between the university, the college, and us on the ground.

She called for better structures to be put in place to:

...secure those layers of communication which are not just operational, but which will provide opportunities for open conversations which really deal with things, with the issues or staff we are all really worrying about. 
Oliver described a lack of honest communication in relation to the possible tensions between the values and expectations of the university and those of the individual academic leader:

My attitude to authority, organizational authority, is to distance myself from the role I'm thrust into, because I think that's the way to get on with people better.

\section{Discussion}

At the beginning of this paper, we set out to answer two key questions, namely, how do Academic Leads describe and understand their experiences of being in the role? And what is the subsequent impact of taking on these new roles on their academic identities and core value systems? In the following section, we discuss our findings in relation to these questions and in the light of the theoretical framework described earlier.

The espoused aims of implementing the distributed leadership model in Sunnyside were to provide more hands-on leadership, guidance, support and advice to individual academic colleagues, as well as to allow more staff to contribute to College wide decision making processes. However, from the data in this study it was clear that, for some, these initial aims were disputed. Issues emerged early on in the process linked to conflicting messages being sent from the University as well as crossed lines of communication within the Colleges, together with a feeling of unease amongst the participants in relation to the two main purposes of the role. In fact, for the majority of Academic Leads, the original purposes of the role covered what were perceived to be two conflicting activities, that of mentoring and managing. While they were happy to mentor academic staff, and indeed saw this as a crucial and very positive aspect of the role, they were much less convinced about the performance management side of being an AL. In short, following Barnett (2011), they were happy to infuse the academics in 
their charge with 'energy and spirit', but less happy to 'manage' academic work and productivity linked to centrally set goals and targets.

Here we begin to see problems linked to 'distributed' academic leaders adhering to different value systems to that of the organisation (set by the Senior Leader/s). Rather than sharing organisational value systems 'congruent with managerial discourse', as seen in Winter's (2009) study, many of the 'distributed' leaders in this study were opposed to them. It appears that several of them were struggling to reconcile the conflicts they were experiencing between their deeply held value systems and identities developed around becoming and being an academic - seeing professional development as a collegial and collaborative activity - with that of being someone who was being asked to make difficult performance management decisions which could affect a colleague's career - in line with more 'managerial' organisational expectations.

This aspect of their role was also seen as more difficult if they perceived that they did not have any real authority (in terms of controlling budgets and workloads) to make significant changes within the structures they were working in. In these cases, the participants felt that, although they were in a nominated leadership position, they lacked any real agency within the tightly controlled organisational structures of the Colleges and University. These findings suggest that, when university leadership is distributed, there can be major accountability issues (as Bolden et al. (2008) have previously alluded to) especially given the increasing pressure on organisations to perform against national and international market driven metrics and benchmarks. The point being made here is that while a number of academic leadership functions may be said to be distributed, in reality the accountability for the success of the institution (and associated external pressures) is not and still lies firmly with more Senior Leader/s, which is why 
they may be reluctant to relinquish control over key areas such as budgets and workloads.

There are some clear messages here in relation to the nature of the 'distributed' Academic Lead role: mixing mentoring and line management is highly problematic. In addition, there are challenges relating to systemic communication issues. However, there are also wider challenges emerging from this case study in relation to the ways in which line management structures and lines of accountability should operate in a complex structure which is focused through one track on research and another on education, and within the context of a disputed notion of what the university is primarily for (Barnett 2011) and what, therefore, the role and focus of an academic leader and indeed any academic should be. These challenges appear to be exacerbated when the identity of the individual Academic Lead is challenged by the possible conflicts between the values and expectations of the institution, with those of individual members of staff and their own.

\section{Conclusions and recommendations}

This study suggests that the challenge of 'distributed leadership' in research-intensive higher education institutions is complex on a number of levels: the plurality of the institutional mission, which includes both research and education, in a rapidly changing international context; the diversity of possible leadership/management roles, ranging from 'line management' to mentoring; the challenge of effective communication in a large, complex organisation; and the effects of traditional academic values and identities, which may support but may also be antithetical to the strategic direction of the institution. 
Distributing leadership has a number of advantages in providing immediate support for academics, but this study suggests that institutions may need to consider carefully a number of questions:

1. Are the purposes, values and strategic direction of the institution clearly articulated, particularly in relation to its expectations for academic staff?

2. Are the 'academic leadership' role profiles clearly articulated and transparent, both to the leaders and to the academics assigned to them, particularly in relation to whether 'academic leads' are line managers or mentors, and where lines of accountability lie?

3. Are internal communications highly effective and sufficiently flexible to meet the needs of a diverse institution?

4. Do institutional practices provide time and opportunity for open discussion about the nuances of, and potential contradictions in, the values and goals of the institution, for example through regular one-toone, team or departmental meetings?

5. Does the institution have a clear strategy for evaluating and enhancing its leadership structure, processes and practices?

Effective leadership models are likely to vary in nomenclature and detail, but the questions posed above, which have arisen directly from the case study presented here, may help institutions evaluate their own roles and structures, and work towards an organisational culture which both manages its 'business' effectively and fosters an atmosphere of 'energy' and 'spirit' (Barnett 2011) which enables academics and academic practices, in all their kaleidoscopic richness, to flourish. 
Acknowledgements

The research presented here was made possible by a grant from the Leadership Foundation for Higher Education. 
Table 1 - Interview Participants

\begin{tabular}{|c|c|c|}
\hline \multicolumn{3}{|c|}{ Academic Leads } \\
\hline Name & $\underline{\text { Age }}$ & Domain \\
\hline Arthur & $30 \mathrm{~s}$ & Natural Sciences \\
\hline Brandon & $60 \mathrm{~s}$ & Natural Sciences \\
\hline Chris & $50 \mathrm{~s}$ & Social Sciences \\
\hline Diane & $40 \mathrm{~s}$ & Social Sciences \\
\hline Evelyn & $50 \mathrm{~s}$ & Social Sciences \\
\hline Francis & $60 \mathrm{~s}$ & Humanities \\
\hline George & $30 \mathrm{~s}$ & Social Sciences \\
\hline Howard & $40 \mathrm{~s}$ & Humanities \\
\hline Ian & $40 \mathrm{~s}$ & Natural Sciences \\
\hline Jack & $30 \mathrm{~s}$ & Humanities \\
\hline Kendra & $50 \mathrm{~s}$ & Humanities \\
\hline Lisa & $50 \mathrm{~s}$ & Social Sciences \\
\hline Martin & $60 \mathrm{~s}$ & Social Sciences \\
\hline Nel & $40 \mathrm{~s}$ & Humanities \\
\hline Oliver & $60 \mathrm{~s}$ & Social Sciences \\
\hline
\end{tabular}


Table 2 - Selected Survey Responses from Academic Leads ( $\mathrm{n}=42$ )

\begin{tabular}{|l|c|c|c|}
\hline \multicolumn{1}{|c|}{ Statements } & $\begin{array}{c}\text { Strongly } \\
\text { Agree/Agree }\end{array}$ & $\begin{array}{c}\text { Neither Agree nor } \\
\text { Disagree }\end{array}$ & $\begin{array}{c}\text { Disagree/Strongly } \\
\text { Disagree }\end{array}$ \\
\hline $\begin{array}{l}\text { I am clear about the purpose of the role } \\
\text { of Academic Lead }\end{array}$ & $29(69 \%)$ & $4(10 \%)$ & $9(21 \%)$ \\
\hline The role boundaries are clearly defined & $13(31 \%)$ & $11(26 \%)$ & $18(43 \%)$ \\
\hline $\begin{array}{l}\text { Information about the role has been } \\
\text { communicated clearly to staff }\end{array}$ & $11(26 \%)$ & $12(29 \%)$ & $19(45 \%)$ \\
\hline $\begin{array}{l}\text { I am happy about the mentoring aspect } \\
\text { of the role }\end{array}$ & $30(71 \%)$ & $5(12 \%)$ & $7(17 \%)$ \\
\hline $\begin{array}{l}\text { I am happy about the management } \\
\text { aspect of the role }\end{array}$ & $13(31 \%)$ & $10(24 \%)$ & $18(43 \%)$ \\
\hline $\begin{array}{l}\text { I think the role should be mainly about } \\
\text { mentoring staff }\end{array}$ & $27(64 \%)$ & $10(24 \%)$ & $5(12 \%)$ \\
\hline $\begin{array}{l}\text { I think the role should be mainly about } \\
\text { managing staff }\end{array}$ & $4(10 \%)$ & $12(29 \%)$ & $26(62 \%)$ \\
\hline $\begin{array}{l}\text { I think that the role should cover both } \\
\text { mentoring and management aspects }\end{array}$ & $16(38 \%)$ & $7(17 \%)$ & $19(45 \%)$ \\
\hline $\begin{array}{l}\text { I understand how the role fits into the } \\
\text { management structure of my college }\end{array}$ & $24(57 \%)$ & $5(12 \%)$ & $13(31 \%)$ \\
\hline
\end{tabular}


Figure 1 - Generic College Management Structure at Sunnyside

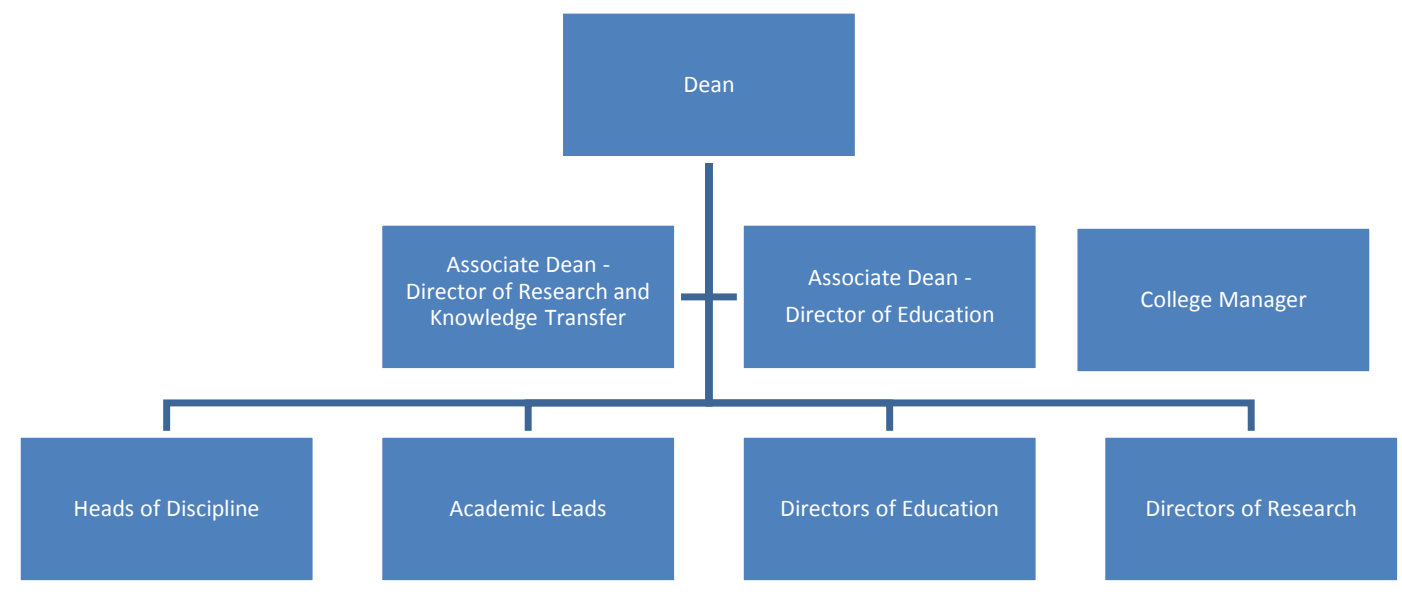


Figure 2 - Survey Breakdown by Job Title

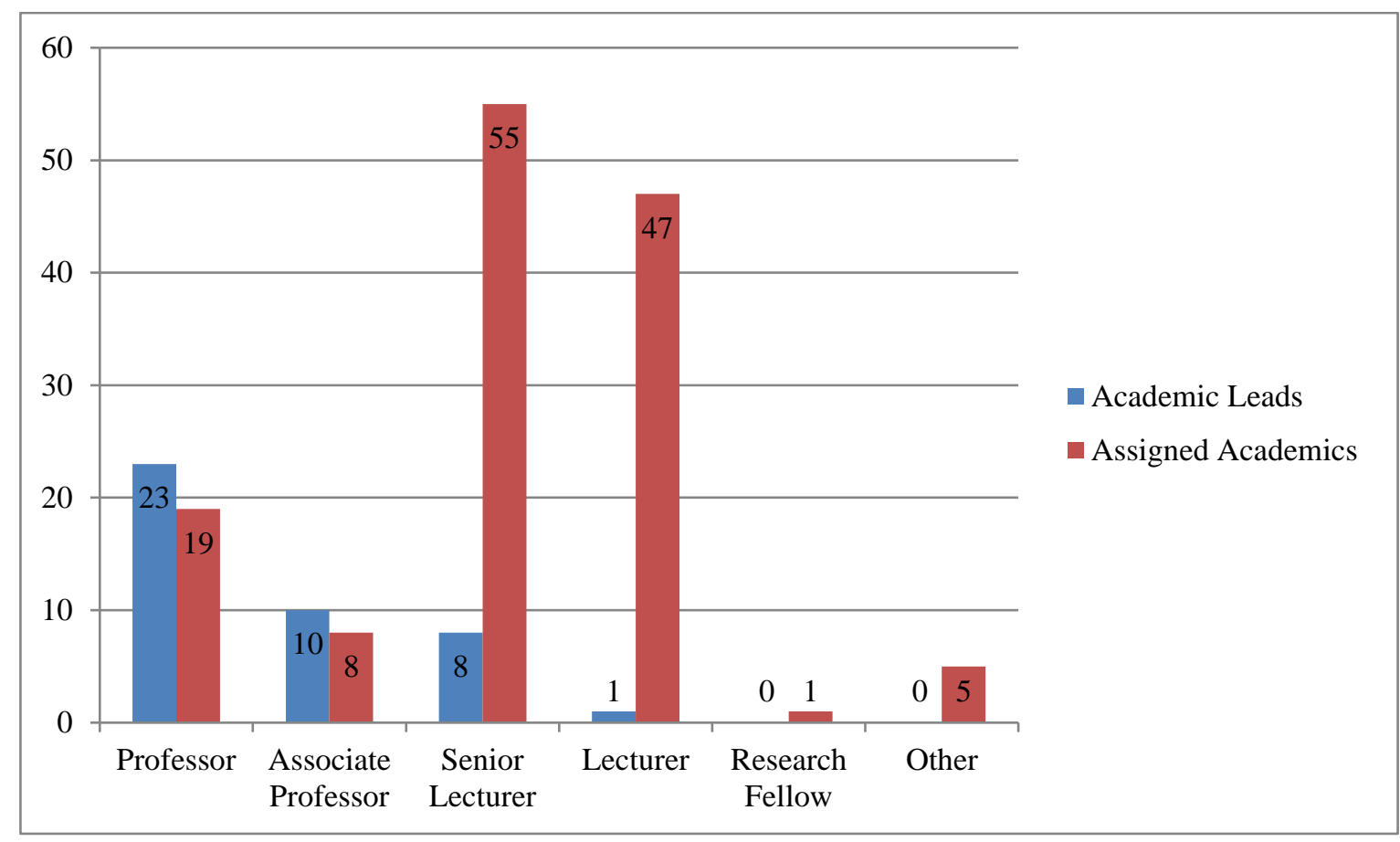




\section{References}

Barber, M., K. Donnelly, and S. Rizvi. 2013. An avalanche is coming: higher education and the revolution ahead. London: Institute for Public Policy Research.

Barnett, R. 2000. Realising the University in an age of supercomplexity. Buckingham: Society for Research into Higher Education and Open University Press.

Barnett, R. 2011. Being a University. Oxford: Routledge.

Bolden, Richard, Jonathan Gosling, and Anne O'Brien. 2013. "Citizens of the academic community? A societal perspective on leadership in UK higher education." Studies in Higher Education 39 (5):754-770. doi: 10.1080/03075079.2012.754855.

Bolden, Richard, Georgy Petrov, and Jonathan Gosling. 2008. "Tensions in Higher Education Leadership: Towards a Multi-Level Model of Leadership Practice." Higher Education Quarterly 62 (4):358-376. doi: 10.1111/j.14682273.2008.00398.x.

Browne, J. 2010. "Independent Review of Higher Education Funding \& Student Finance." Accessed 21st May 2012. http://webarchive.nationalarchives.gov.uk/+/hereview.independent.gov.uk/herev iew/report/.

Bryman, A. 2007. "Effective leadership in higher education: a literature review." Studies in Higher Education 32 (6):693-710.

Bryman, A. 2008. Social Research Methods. Third ed. Oxford: Oxford University Press.

Bryman, A. 2009. Effective Leadership in Higher Education. London: Leadership Foundation for Higher Education.

Cresswell, J. 2014. Research Design. fourth ed. London: Sage.

Flumerfelt, S., and M. Banachowski. 2011. "Understanding leadership paradigms for improvement in higher education." Quality Assurance in Education 19 (3):224247.

Gronn, P. 2008. "The future of distributed leadership." Journal of Educational Administration 46 (2):141-158.

Harkin, Damien G., and Annah H. Healy. 2013. "Redefining \& leading the academic discipline in Australian universities." Australian Universities' Review 55 (2):8092.

Holt, Dale, Stuart Palmer, Maree Gosper, Michael Sankey, and Garry Allan. 2014. "Framing and enhancing distributed leadership in the quality management of online learning environments in higher education." Distance Education 35 (3):382-399. doi: 10.1080/01587919.2015.955261.

Holt, Dale, Stuart Palmer, Judy Munro, Ian Solomonides, Maree Gosper, Margaret Hicks, Michael Sankey, Garry Allan, and Robert Hollenbeck. 2013. "Leading the quality management of online learning environments in Australian higher education." Australasian Journal of Educational Technology 29 (3):387-402.

Jones, Sandra, Marina Harvey, Geraldine Lefoe, and Kevin Ryland. 2014. "Synthesising theory and practice: Distributed leadership in higher education." Educational Management Administration \& Leadership 42 (5):603-619. doi: 10.1177/1741143213510506.

Jones, Sandra, Geraldine Lefoe, Marina Harvey, and Kevin Ryland. 2012. "Distributed leadership: a collaborative framework for academics, executives and professionals in higher education." Journal of Higher Education Policy \& Management 34 (1):67-78. doi: 10.1080/1360080X.2012.642334. 
Kezar, Adrianna, Tricia Bertram Gallant, and Jaime Lester. 2011. "Everyday people making a difference on college campuses: the tempered grassroots leadership tactics of faculty and staff." Studies in Higher Education 36 (2):129-151. doi: 10.1080/03075070903532304.

Lichtman, M. 2010. Qualitative Research in Education: A user's guide. Second ed. Thousand Oaks, California: Sage.

Mayrowetz, D. 2008. "Making Sense of Distributed Leadership: Exploring the Multiple Usages of the Concept in the Field." Educational Administration Quarterly 44 (3):424-435.

Newby, P. 2010. Research Methods for Education. Harlow, Essex: Pearson Education Ltd

Osseo-Asare, A. E., D. Longbottom, and P. Chourides. 2007. "Managerial leadership for total quality improvement in UK higher education." The TQM Magazine 19 (6):541-560.

Randall, L. M. , and L. A. Coakley. 2007. "Applying adaptive leadership to successful change initiatives in academia." Leadership \& Organization Development Journal 28 (4):325-335.

Spillane, J. P., R. Halverson, and J. B. Diamond. 2007. "Towards a theory of leadership practice: a distributed perspective." Journal of Curriculum Studies $36(1): 3-34$.

Winter, R. 2009. "Academic manager or managed academic? Academic identity schisms in higher education." Journal of Higher Education Policy and Management 31 (2):121-131.

Woods, P. A., N. Bennett, J. A. Harvey, and C. Wise. 2004. "Variabilities and Dualities in Distributed Leadership." Educational Management Administration \& Leadership 32 (4):439-457. 